\title{
DINAMIKA KEJAHATAN DUNIA MAYA MENGENAI ONLINE CHILD SEXUAL EXPLOITATION DI TENGAH PANDEMI COVID-19
}

\author{
Samsul Arifin', Kholilur Rahman ${ }^{2}$ \\ *Fakultas Hukum Universitas Airlangga \\ Email: samsul.arifin-2019@fh.unair.ac.idㄴㅐㅐolilurrahman.jurists@gmail.com²
}

\begin{abstract}
Abstrak
Sekarang ini seluruh dunia tengah mendapati ancaman Pandemi COVID-19, kondisi demikian telah mengganti sikap sosial anak serta remaja yang ditutup sekolahnya lebih banyak menghabiskan waktu secara online. Perubahan sikap ini berdampak pada bidang kejahatan dunia maya, khususnya dalam bentuk eksploitasi seksual baru yang berkembang saat ini dengan memanfaatkan sarana internet (online child sexual exploitation) yang terindikasi semakin merebak di tengah Pandemi COVID-19. Selain itu, Salah satu permasalahan yang muncul adalah tidak konsistennya penggunaan istilah atau terminologi terkait eksploitasi seksual anak secara online, sehingga berdampak pada kesulitan dalam penegakan hukum (law enforcement). Metode yang digunakan dalam penelitian ini ialah penelitian hukum doktrinal dengan pendekatan perundang-undangan (Statute Approach) sebagai sumber hukum utama. Penelitian ini bermaksud untuk menguraikan mengenai terminologi dan karakteristik online child sexual exploitation dalam perspektif hukum positif, serta identifikasi dinamika kejahatan dunia maya mengenai online child sexual exploitation di tengah Pandemi COVID-19. Dari hasil penelitian dapat diketahui bahwa dampak pandemic COVID-19 telah mendorong sikap anak lebih intim dengan Gadget, sehingga menimbulkan banyak persolaan baru khususnya dalam penegakan hukum pidana.
\end{abstract}

Kata Kunci: Dinamika; Online Child Sexual Exploitation; Pandemi COVID-19

\begin{abstract}
Currently the world is finding the threat of covid-19 pandemics, such conditions have replaced the social attitudes of children and adolescents who have been shut out of school spend more time online. This change in attitudes has affected the field of online crime, especially in the form of new sexual exploitation today by utilizing the indicated Internet tool (online child sexual abuse), increasingly proliferating in the covid-19 pandemic. Moreover, one of the problems that arise is the inconsistency of using terms or terminology regarding child sexual exploitation online, which is consequent to law enforcement. The method used in the study was the study of doctrinal law with the constitutional approach (approach approach) as the main source of the law. The study intends to describe the terminology and characteristics of the online
\end{abstract}


child sexual characteristics ina positive legal perspective, as well as an identification of online child sexual dynamics in the middle of the covid-19 pandemic. Studies have shown that the cumulative covid-19 effects have encouraged children's increased intimacy with gadgets, resulting in a lot of new funding especially in criminal law enforcement.

\section{Keyword: dynamics; Online Child Sexual Exploitation; COVID-19 pandemic}

\section{PENDAHULUAN}

Dalam sejarah peradaban manusia kejahatan bukanlah suatu konsep yang baru. Bahkan teori-teori kejahatan juga berkembang signifikan. Hal ini disebabkan karena kejahatan merupakan salah satu fitrah manusia yang ada dalam diri manusia dan akan mengalami perkembangan signifikan dengan mengikuti perkembangan masyarakat itu sendiri. Thomas Hobbes, mengenalkan istilah "homo homini lupus" artinya manusia adalah serigala bagi sesamanya. ${ }^{1} \mathrm{Hal}$ tersebut juga selaras dengan pendapat Freund yang mengemukakan "bahwa hasrat untuk merusak manusia sama dengan hasrat untuk mencintai".

Ditambah lagi perubahan pada pola hidup bermasyarakat di tengah Pandemi COVID-19 yang lebih cenderung melaksanakan segala kegiatan secara daring, dan tidak hanya digunakan oleh kalangan dewasa saja tetapi juga digunakan oleh anakanak. ${ }^{2}$ Howard Taylor, selaku Executive Director Global Partnership to End Violence mengatakan bahwa: "Pandemi COVID-19 mengakibatkan terdapatnya penutupan sekolah serta langkah-langkah pengendalian yang ketat". ${ }^{3}$ UNICEF mengatakan lebih dari 1,5 miliyar anak serta remaja yang ditutup sekolahnya lebih banyak menghabiskan waktu secara daring ataupun online. ${ }^{4}$ Perihal ini, hendak berpotensi pada peningkatan kejahatan dunia maya (cyber crime) baik anak sebagai pelaku kejahatan semacam halnya illegal contents, ataupun anak sebagai korban semacam online child sexual exploitation.

Bentuk eksploitasi seksual baru yang berkembang dikenal sebagai online child sexual exploitation. Pada beberapa kasus eksploitasi seksual dalam skala kecil telah

1 J. K. Veegar, Realitas Social, Gramedia Pustaka Utama, Jakarta, 1990, h. 68.

${ }^{2}$ Teknologi informasi mengalami perkembangan yang sangat pesat di berbagai negara termasuk di Indonesia. Kemajuan teknologi informasi ini membawa pengaruh baik dalam perkembangan ekonomi, serta perolehan informasi yang cepat dari seluruh dunia. Namun disamping membawa pengaruh yang baik, perkembangan teknologi informasi juga membawa pengaruh buruk. Seperti halnya maraknya kejahatan dunia maya atau cybercrime yang merupakan bagian dari akibat buruk yang timbul dari kemajuan teknologi informasi. Lihat M Syukri Akub, 'Pengaturan Tindak Pidana Mayantara (Cyber Crime) dalam Sistem Hukum Indonesia', jurnal Ilmiah hukum Universitas Muslim Indonesia, Vol 20, No 2, 2018, h. 85.

${ }^{3}$ Giovani Dio Prasasti, UNICEF: Waspadai Kejahatan pada Anak di Dunia Maya Selama Pandemi COVID-19,https://m.liputan6.com/health/read/4235421/unicef-waspadai-kejahatan-pada-anak-di dunia-maya-selama-pandemi-covid-19, diakses tanggal 11 November 2020.

$$
{ }^{4} \text { Ibid. }
$$


ditemukan di Philipina dan Thailand, yaitu kasus grooming (bujuk rayu seksual), penyebaran konten pornografi anak, bahkan ajakan dalam bentuk sexting (mengirimkan gambar yang tidak senonoh) sudah terjadi di kedua negara tersebut. Sedangkan di Philipina, Thomson Reuters Foundation telah menemukan kasus baru seperti live streaming sexual abuse pada anak-anak. ${ }^{5}$

Dinamika kejahatan dunia maya dalam bentuk online child sexual exploitation ini juga telah berkembang di Indonesia di tengah Pandemi COVID-19. Terlebih lagi, terdapat kesulitan dalam mengidentifikasi dan menyelidiki pelanggar, dikarenakan mereka dapat terus menyesuaikan teknologi untuk memungkinkan pelecehan dan eksploitasi seksual mereka, dan menghindari deteksi. Selain itu, Salah satu permasalahan yang sering muncul ialah tidak konsistennya pemakaian istilah atau terminologi pada penegakan hukum. Meski sudah terdapat definisi hukum berkaitan dengan beberapa tindak kriminal eksploitasi di Indonesia khususnya anak, sisanya terdapat banyak pemakaian istilah yang tidak sama.

Maka, butuh kegamblangan konsep dalam terminologi terkait eksploitasi dan penjabaran karakteristik kejahatan dunia maya mengenai online child sexual exploitation. Berdasarkan kondisi tersebut, perlu kiranya menguraikan dan menjelaskan mengenai terminologi dan karakteristik kejahatan dunia maya mengenai online child sexual exploitation dalam perspektif hukum positif. Selain itu, Artikel ilmiah ini juga mengidentifikasi dinamika online child sexual exploitation di tengah Pandemi COVID-19. Sehingga, para pemangku kepentingan khususnya dalam proses penegakan hukum (law enforcement) dapat mengetahui perkembangan dan dinamika kejahatan dunia maya mengenai online child sexual exploitation di tengah Pandemi COVID-19.

Berdasarkan pada uraian di atas, artikel ilmiah ini bermaksud untuk menguraikan dan menjelaskan dengan rumusan permasalahan, pertama, terminologi dan karakteristik kejahatan dunia maya mengenai online child sexual exploitation dalam perspektif hukum positif. kedua, identifikasi dinamika kejahatan dunia maya mengenai online child sexual exploitation di tengah Pandemi COVID-19.

\section{METODE PENELITIAN}

Metode yang digunakan dalam penelititan ini adalah analisis deskriptif dan/atau penelitian hukum normatif, yakni dengan memberikan pemahaman pendekatan penerapan undang-undang (Statute Aprroach) terkait, dalam hal pemberantasan tindak pidana eksploitasi terhadap anak. Dalam metode Statute Aproach penulis harus memahami terkait dengan hirarki dan asas-asas dalam peraturan perundang-undang yang menjadi rujukan ${ }^{6}$.

5 Ahmad Sofian, Perlindungan Anak dari Eksploitasi Seksual Online Selama Covid-19, https://business-law.binus.ac.id/2020/05/29/perlindungan-anak-dari-eksploitasi-seksual-onlineselamacovid-19/, diakses tanggal 10 November 2020.

${ }^{6}$ Peter Mahmud Marzuki, Penelitian Hukum, Prenada Media Grup, Jakarta, 2016, Hal 137 
Penelitian ini menggunakan metode pengumpulan data dari kepustakaan, yakni dengan mencari Pustaka yang dirasa cukup relevan dengan isu yang dikaji. Pengumpulan data tersebut difokuskan terhadap bahan hukum primer, yakni peraturan perundang-undangan. bahan hukum sekunder, yakni referensi Pustaka dan jurnal yang sesuai dengan objek penelitian,

\section{HASIL PENELITIAN DAN PEMBAHASAN}

\section{Terminologi dan Karakteristik Kejahatan Dunia Maya mengenai Online Child Sexual Exploitation dalam Perspektif Hukum Positif}

Para kriminolog membedakan antara perbuatan mala prohibita dan mala in se. perbuatan-perbuatan yang didefinisikan sebagai mala prohibita merujuk pada perbuatan yang buruk karena dilarang, sedangkan perbuatan mala in se dimaknai sebagai perbuatan yang buruk dengan sendirinya. ${ }^{7}$ Eksploitasi seksual anak dapat dikategorikan sebagai perbuatan yang buruk karena dilarang, sebab dalam hukum positif Indonesia kejahatan tersebut diatur dalam beberapa peraturan perundangundangan.

Muhammad Mustofa selaku Guru Besar Fakultas Ilmu Sosial dan Ilmu Politik Universitas Indonesia, memberikan pemahaman bahwa:

"Kriminologi harus dapat berfungsi menerangkan indikasi kejahatan dalam bermacam kondisi. Sekarang ini seluruh dunia tengah mendapati ancaman Pandemi COVID-19. Pandemi COVID-19 sudah mengganti sikap sosial warga masyarakat, pergantian sikap tersebut pula terjadi dalam bidang kriminalitas. Teknologi cyber jadi alternatif metode berhubungan sosial ketika terjadi Pandemi COVID-19". 8

Eksploitasi seksual anak telah meningkat dengan memakai sistem online. Dilihat dari pengertiannya, online child sexual exploitation atau dapat juga disebut eksploitasi seksual anak online merupakan wujud eksploitasi seksual anak yang bisa berbentuk desakan, ataupun manipulasi sebagai penciptaan ataupun menghasilkan konten yang berisi seksual kepada anak untuk memanfaatkan fasilitas jaringan atau internet. ${ }^{9}$ Pada perbuatan eksploitasi seksual anak online, hal yang sangat berarti yaitu pemakaian Internet sebagai fasilitas dalam keberlangsungan eksploitasi seksual kepada anak. Wujud eksploitasi seks anak online ini tercantum pula pada sexting serta grooming.

7 Frank E. Hagan, Pengantar Kriminologi: Teori, Metode, dan Perilaku Kriminal, Pranadamedia, Jakarta, 2013, h. 11.

8 Webinar FISIP UI 2020, Mencegah dan Membatasi Cyber Crime di Masa Pandemi, https://fisip.ui.ac.id/mencegah-dan-membatasi-cyber-crime-di-masa-pandemi/, diakses tanggal 20 November 2020.

9 Juliane A. Kloess, Anthony R. Beech and Leigh Harkins, 'Online Child Sexual Exploitation: Prevalence, Process, and Offender Characteristics', Trauma, Violence, E Abuse , Vol. 15 (2), 2014, 2014, h. 127. 
NCMEC (National Center for Missing E Exploited Children), menyatakan "Internet Sexual Exploitation could be in the form of enticement, unlawful soliciting, or illegally exposing of a minor to sexually explicit behavior". ${ }^{10}$ Artinya bahwa Eksploitasi Seksual Internet dapat dalam bentuk bujukan atau rayuan, permintaan yang melanggar hukum, atau secara ilegal mengekspos anak di bawah umur ke perilaku seksual.

Terminologi atau istilah mengenai "eksploitasi seksual anak online" ialah ekspansi dari istilah "eksploitasi seksual anak". Undang-undang di Indonesia tidak mengatur "eksploitasi seksual anak" pada satu undang-undang ataupun undangundang tersendiri. Beberapa peraturan yang masih relevan untuk dijadikan rujukan mengenai eksploitasi seksual anak online, yaitu pengaturan yang tersebar pada beberapa peraturan perundang-undangan seperti, UU Perlindungan Anak, UU ITE, UU TPPO, dan UU Pornografi. ${ }^{11}$ Seperti yang di uraikan pada Tabel 1.

Table 1. Peraturan yang relevan tentang eksploitasi seksual anak.

\begin{tabular}{|c|c|}
\hline $\begin{array}{l}\text { Undang- } \\
\text { Undang }\end{array}$ & Uraian \\
\hline $\begin{array}{lll}\text { UU } & \text { No. } & 44\end{array}$ & Perbuatan yang dilarang: \\
\hline $\begin{array}{l}\text { Tahun } 2008 \\
\text { tentang } \\
\text { Pornografi }\end{array}$ & $\begin{array}{l}\text { Memproduksi, membuat, memperbanyak, menggandakan, } \\
\text { menyebarluaskan, menyiarkan, mengimpor, mengekspor, } \\
\text { menawarkan, memperjualbelikan, menyewakan, atau } \\
\text { menyediakan pornografi, (Pasal } 4 \text { ). } \\
\text { Ancaman hukuman: } \\
\text { Ancaman hukuman pidana } 6 \text { bulan s/d } 12 \text { tahun dan/atau } \\
\text { denda Rp. } 250 \text { juta s/d } 6 \text { miliar, (Pasal } 45 \text { ayat } 1 \text { ). }\end{array}$ \\
\hline UU $\quad$ No. 17 & Perbuatan yang dilarang: \\
\hline $\begin{array}{l}\text { Tahun } 2016 \\
\text { tentang } \\
\text { Perlindungan } \\
\text { Anak }\end{array}$ & $\begin{array}{l}\text { Eksploitasi Seksual Anak, (pasal } 76 \text { I). } \\
\text { Ancaman hukuman: } \\
\text { Ancaman hukuman pidana maksimum } 10 \text { tahun dan/atau } \\
\text { denda maksimum } 200 \text { juta rupiah, (Pasal 88). }\end{array}$ \\
\hline UU $\quad$ No. 21 & Perbuatan yang dilarang: \\
\hline $\begin{array}{l}\text { Tahun } 2007 \\
\text { tentang TPPO }\end{array}$ & $\begin{array}{l}\text { Perekrutan, pengangkutan, penampungan, pengiriman, } \\
\text { pemindahan, atau penerimaan seseorang dengan ancaman } \\
\text { kekerasan, penggunaan kekerasan, penculikan, penyekapan, } \\
\text { pemalsuan, penipuan, penyalahgunaan kekuasaan atau posisi } \\
\text { rentan, penjeratan utang atau memberi bayaran atau manfaat } \\
\text { walaupun memperoleh persetujuan dari orang yang } \\
\text { memegang kendali atas orang lain, untuk tujuan }\end{array}$ \\
\hline
\end{tabular}

10 Abimbola-Akinola, Dickson A., The Cyber Crime and Internet and Internet Sexual Exploitation of Children, All Student Theses Governors State University, Amerika Serikat, 2017, h. 13.

${ }_{11}$ Valentina Gintings et al, Buku Panduan Terminologi Perlindungan Anak dari Eksploitasi, Deputi Bidang Perlindungan Anak Kementerian Pemberdayaan Perempuan dan Perlindungan Anak, Jakarta, 2019, h. 28. 


\begin{tabular}{|c|c|}
\hline & $\begin{array}{l}\text { mengeksploitasi orang tersebut di wilayah negara Republik } \\
\text { Indonesia, (Pasal } 2 \text { ayat } 1 \text { ). } \\
\text { Ancaman hukuman: } \\
\text { Ancaman hukuman pidana } 3 \text { bulan s/d } 15 \text { tahun dan/atau } \\
\text { denda Rp. } 120 \text { juta s/d } 600 \text { juta, (Pasal } 2 \text { ayat } 1 \text { ). }\end{array}$ \\
\hline UU $\quad$ No. 19 & Perbuatan yang dilarang: \\
\hline $\begin{array}{l}\text { Tahun } 2016 \\
\text { tentang ITE }\end{array}$ & $\begin{array}{l}\text { Mendistribusikan dan/atau mentransmisikan dan/atau } \\
\text { membuat dapat diaksesnya Informasi Elektronik dan/atau } \\
\text { Dokumen Elektronik yang mengandung pelanggaran } \\
\text { kesusilaan, (Pasal 27). } \\
\text { Ancaman hukuman: } \\
\text { Dengan ancaman hukuman pidana maksimum } 6 \text { tahun } \\
\text { dan/atau denda maksimum satu miliar rupiah, (Pasal } 45 \text { ayat } \\
\text { 1). }\end{array}$ \\
\hline
\end{tabular}

Sumber: diolah penulis, 2020

Kekurangan yang ada pada hukum positif negara Indonesia, yaitu belum ada ketentuan-ketentuan yang mengatur secara khusus mengenai eksploitasi seksual anak dengan memakai jaringan internet, dan juga masih abstraknya definisi terkait istilah tindak pidana eksploitasi seksual anak pada peraturan perundang-undangan. Karena dalam sejumlah kasus perbuatan eksploitasi seksual anak dengan pemanfaatkan fasilitas jaringan komunikasi ini dapat leluasa bebas dari ancaman hukuman, dengan dasar bahwa dalam hukum positif tidak ada ketentuan-ketentuan secara khusus terkait eksploitasi seksual anak melalui online. ${ }^{12}$

Salah satu peraturan yang menjelaskan atau menerangkan eksploitasi seksual anak di bidang online yaitu Protokol Opsional Konvensi Hak Anak terkait Penjualan Anak, Pornografi Anak, Prostitusi Anak. Oleh sebab itu, artikel ilmiah ini menganjurkan referensi eksploitasi seksual anak online secara universal dengan mengacu pada pengertian yang tertuang pada protokol tersebut, sebagaimana telah dipaparkan pada Pasal 3, yaitu: "mengkriminalisasi seluruh ragam tindakan membuat, mendistribusikan, menyebarluaskan, mengimpor, mengekspor, menawarkan, menjual ataupun mempunyai konten yang bermuatan pornografi anak". Ketentuan ini bisa dikatakan sebagai ketentuan awal yang tidak membolehkan menyebarkan informasi yang berisikan pornografi anak pada bentuk apa saja, meskipun lewat sarana online. Akan tetapi Indonesia tetap harus senantiasa merumuskan ketentuan-ketentuan khusus mengenai eksploitasi seksual anak secara online ini. ${ }^{13}$

12 Ibid.

13 Indonesia tertulis sebagai negara yang antusias dalam mengatasi "eksploitasi seksual anak". Perihal ini terbukti bahwa Indonesia telah meratifikasi UNCRC sejak tahun 1990, dan melibatkan Indonesia harus menerapkan seluruh ketentuan yang terdapat pada UNCRC, paling utama mengenai "eksploitasi seksual anak". Katakan saja sebagian aturan yang mengendalikan tentang "eksploitasi seksual anak" semacam UU Proteksi Anak, UU Pornografi, UU TPPO dilakukan supaya sesuai sama 


\section{Identifikasi Dinamika Kejahatan Dunia Maya Mengenai Online Child Sexual Exploitation (Cyber Sex) Di Tengah Pandemi COVID-19}

Jay Phelan, seorang professor biologi di Universitas California Los Angeles (UCLA) sebagaimana dikutip oleh Ummu Hani, dkk, menyebutkan bahwa pornografi dan seksualitas pada dasarnya adalah masalah kontrol diri, yang lebih menitik beratkan kepada individu dalam kemampuannya mengamati situasi diri dan lingkungan yang ditunjukkan untuk menampilkan diri, melakukan sosialisasi, kemampuan pengendalian perilaku, kemampuan menarik perhatian, kemampuan mengubah diri sesuai dengan pendapat orang lain, bahkan sampai dengan kemampuan diri untuk menyembunyikan perasaan ${ }^{14}$.

Ketika seseorang mendengar kata "seks" yang terlintas dipikirannya adalah interaksi dua orang atau lebih yang mengarah kepada kepuasan Hasrat orientasi seksual masing-masing. Bukti nyata lain dari perkembangan teknologi ialah bergesenya paradigma terkait dengan seks tersebut, hal ini dibuktikan dengan munculnya istilah Cyber Sex, ada beberapa istilah lain, ada yang menyebutnya computer sex, dan internet sex. Yakni perjumpaan secara virtual yang mengarah kepada hal-hal yang berkaitan dengan seksualitas, dimana dua orang atau lebih yang terpisah saling terhubung melalui suatu sarana (telepon, computer, atau internet) dan saling bertukar pesan yang bermuatan seks secara eksplisit untuk menggambarkan bagaimana pengalaman seksualnya ${ }^{15}$.

Setidaknya ada tiga karakteristik umum yang melekat terhadap penggunaan diksi cyber sex, yakni:

1. Aksesibilitas

Untuk saat ini, akses terhadap segala hal dalam dunia cyber semakin mudah, tidak hanya bagi orang dewasa saja, anak-anak pun dengan mudah mengakses hal apapun yang mereka inginkan. Hal ini diperparah dengan adanya pandemi COVID-19, dimana segala aktivitas manusia harus dilaksanakan secara daring. Hal ini pula yang membuat hubungan manusia dan dunia cyber semakin intim.

2. Keterjangkauan

Sampai saat ini operator penyedia layanan internet terus membenahi akses internet mereka, sampai ke desa yang terpencil sekalipun bisa dijangkau oleh internet, serta harga yang cukup murah sehingga bisa menjangkau semua golongan masyarakat.

3. Anonimitas

Seseorang akan dengan mudah berinteraksi dengan orang lain tanpa mengenalnya, tidak sedikit dari mereka yang menyembunyikan data diri yang

\footnotetext{
aturan-aturan yang diatur pada UNCRC. Tetapi, dengan pertumbuhan teknologi wujud ekspoitasi seksual anak bukan lagi memakai cara yang biasa. Lihat Ibid, h. 61.

${ }^{14}$ Ummu Hani, dkk. "Kontrol Diri Terhadap Perilaku Cyber Sex Pada Remaja". PSYCHOPOLYTAN jurnal psikologi, Vol 3, No 2, Februari 2020 Hal 126-132

${ }^{15}$ Budi Irawanto, "Mereguk Kenikmatan Di Dunia Maya Virtualitas Dan Penubuhan Dalam Cyber Sex", kawistara, vol 7, no 1, 22 april 2017, hal 30-40
}

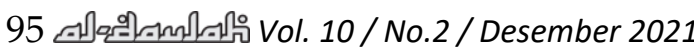


asli, hal ini dilakukan guna dapat mencapai kepuasan yang mereka inginkan tanpa ada rasa khawatir bahwa dirinya akan selalu dibuntuti oleh partnernya ${ }^{16}$.

Asosiasi penyelenggara jasa internet Indonesia (APJII), sebagaimana disampaikan dalam laporan survei internet APJII 2019-2020 (Q2), dari 266.91 juta populasi penduduk Indonesia, ada sekitar 196.71 juta jiwa yang menjadi pengguna aktif mengakses internet, yang jika di presentasikan mencapai 73,7\%. Tentu angka tersebut semakin meningkat ditengah pandemi COVID-19, hal ini tidak lepas dari kebijakan pemerintah yang mengharuskan segala hal dikerjakan dari ruman (daring) ${ }^{17}$.

Dari penjelasan tersebut, secara sederhana kita pahami bahwa gelombang pergeseran paradigma terkait dengan seks tidak hanya terbatas kepada pertemuan secara fisik saja. Timbulnya aktivitas tersebut juga akan berdampak terhadap perubahan kebijakan yang akan diambil oleh pemerintah, salah satunya terkait dengan kebijakan hukum pidana, karna tidak sedikit terjadi kejahatan kesusilaan yang semakin hari permasalahannya semakin kompleks.

International Crime Statistics (Statistik Kejahatan Internasional) menunjukkan telah ada penurunan yang stabil mengenai pelecehan seksual terhadap anak secara langsung. Satu-satunya pengecualian untuk tren ini adalah peningkatan pornografi anak melalui Internet. ${ }^{18}$ Andy Ardian, sebagai Program Manager ECPAT Indonesia, menjelaskan bahwa:

"Kejahatan yang sangat perlu untuk diwaspadai yaitu online child sexual exploitation. Dimana, wujudnya bisa berupa perbuatan yang menampilkan kekerasan maupun eksploitasi anak, sexting, (pemerasan seksual), grooming (pedekate sebagai tujuan seksual online), hingga live streaming (siaran langsung sebagai bentuk kekerasan seksual pada anak). Kenyataannya, eksploitasi seksual anak online terindikasi semakin merebak di tengah Pandemi COVID-19". ${ }^{19}$

Laporan tentang eksploitasi seksual anak online yang diterima NCMEC (National Center for Missing and Exploited Children) pada April 2020, telah mencatat bahwa 4,2 juta konten eksploitasi seksual anak yang didistribusikan ataupun diakses. Jumlah ini bertambah 2 juta dalam sebulan dibandingkan pada informasi bulan Maret 2020. ${ }^{20}$ Identifikasi ini menunjukkan bahwa dengan berkembangnya teknologi informasi yang telah menjadi bagian integral dari kehidupan modern dan memainkan

16 Ibid

17 Disampaikan dalam laporan survei internet APJII 2019-2020 Q2.

18 Ly, T., Murphy, L and Fedoroff, J.P. 'Understanding Online Child Sexual Exploitation Offenses', Curr Psychiatry Rep, Vol 18, No 74, 2016, h. 2.

19 Siaran Pers Nomor: B-108/Set/Rokum/MP 01/06/2020, Hindari Kejahatan Online, Lakukan Edukasi Aman Internet Anak Berulang Kali, https://www.kemenpppa.go.id/index.php/page/read/29/2731/hindari-kejahatan-online-lakukanedukasi-internet-aman-untuk-anak-berulang-kali, diakses tanggal 20 November 2020.

${ }^{20}$ Ibid. 
peran penting di tengah Pandemi COVID-19 ini, sehingga menjadikan anak semakin rentan terhadap bentuk eksploitasi seksual baru yang terus berkembang.

Dinamika kejahatan dunia maya dalam bentuk eksploitasi seksual baru ini, pada dasarnya merupakan eksploitasi seksual anak secara online sebagai kemajuan dari eksploitasi seksual anak dengan universal telah lebih dikenal. ${ }^{21}$ Eksploitasi seksual anak secara online mengacu pada kriminal yang dilakukan oleh pelanggar yang menggunakan Teknologi Komunikasi Informasi dan/atau Internet sebagai fasilitas dalam melakukan pelecehan seksual terhadap anak.

Dinamika online child sexual exploitation atau eksploitasi seksual anak secara online mempunyai macam-macam bentuk yang terus berganti bersamaan dengan pertumbuhan teknologi. Bentuk eksploitasi seksual anak online telah sempat terjalin serta berkembang di Indonesia selama Pandemi COVID-19, ialah: grooming, sexting serta perihal kekerasan seksual yang ditayangkan dengan terus atau langsung.

1. Sexting, ialah aktivitas mengirimkan atau menerima foto bermuatan intim, sebagian permasalahan sexting mulai ditemui dan berlangsung di bermacam daerah negara kita. Contohnya pada wujud percakapan memiliki nuansa kenikmatan antar anak muda, sama-sama memberikan foto, lukisan serta video kenikmatan di golongan anak muda, serta bentuk- bentuk sexting yang lain. ${ }^{22}$

2. Grooming online, ialah satu dari wujud eksploitasi seksual anak secara online dengan cara bujuk rayu dengan keinginan seksual secara online. Rayuan serta bujukan anak dengan tujuan seksual tersebut kerap dipicu dengan "grooming" ataupun "grooming online". Permintaan anak bisa ditafsirkan untuk suatu aplikasi yang mana kedewasaan "bergaul" sama seseorang anak. ${ }^{23}$

3. Paksaan seksual yang ditayangkan dengan langsung, Sebutan kekerasan intim yang ditayangkan secara langsung masih belum banyak digunakan. Mayoritas di Indonesia lebih dikenal dengan sebutan Video Call Sex (VCS). ${ }^{24}$

Dalam hukum positif di Indonesia belum diatur ketentuan-ketentuan mengenai 3 (tiga) Wujud eksploitasi seksual anak online seperti grooming, sexting serta kekasaran seksual yang ditayangkan langsung. Padahal dinamika kejahatan dunia maya tentang eksploitasi seksual anak melalui online ini sangatlah penting dirumuskan dalam peraturan perundang-undangan, manakala melihat perkembangan teknologi yang ada.

\section{KESIMPULAN}

Artikel ini menyimpulkan sebagai berikut: pertama, terjadinya pergeseran paradigma terkait dengan hubungan seksualitas, bahwa hubungan seks tidak hanya sebatas bertemunya dua orang atau lebih lalu bersenggama. terlepas dari itu semua, Cyber Sex telah membuat hubungan manusia dengan perangkat gadget menjadi

\footnotetext{
${ }^{21}$ Valentina Gintings et al , Op. Cit, h. 51.

${ }^{22} \mathrm{Ibid}, \mathrm{h} .66$.

${ }^{23}$ Oxford Advanced Learner's Dictionary, dalam Ibid, h. 78.

${ }^{24} \mathrm{Ibid}$, h. 84.
} 
semakin intim. Kedua, istilah "Online Child Sexual Exploitation" ialah ekspansi dari terminologi "eksploitasi seksual anak". Terdapat kekosongan hukum terkait pengaturan tentang eksploitasi seksual anak dengan menggunakan cara internet, dan juga masih abstraknya terminologi terkait perbuatan kejahatan eksploitasi bagi anak pada peraturan perundang-undangan. Ketiga, bahwa dinamika eksploitasi seksual anak online terindikasi semakin marak terjadi di tengah Pandemi COVID-19, hal ini berdasar pada laporan mengenai eksploitasi seksual anak online yang diterima NCMEC pada April 2020, yang bertambah 2 juta dalam sebulan dibandingkan pada informasi bulan Maret 2020. Bentuk kejahatan ini ialah: sexting, grooming, serta kekerasan seksual secara online.

Berpijak pada hasil penelitian dan analisa serta kesimpulan seperti yang dijelaskan diatas maka dapat direkomendasikan sebagai berikut: pertama, melakukan pembentukan atau perubahan ketentuan-ketentuan dalam peraturan perihal eksploitasi seksual anak online, untuk mempertegas penggunaan terminologi eksploitasi seksual kepada anak, serta sebagai perumusan eksploitasi seksual anak online dengan ketentuan tindak pidananya. Kedua, artikel ini juga merekomendasikan, bahwa pemerintah Indonesia supaya lekas melaksanakan ulasan, kajian yang luas dan lengkap, serta pembinaan khusus bagi anak dalam mengguakan internet selama Pandemi COVID-19, untuk menghindari penyalahgunaan internet atau media sosial oleh anak sehingga tidak terpengaruh kedalam kejahatan dunia maya khususnya online child sexual exploitation.

\section{DAFTAR PUSTAKA}

\section{Buku}

Abimbola-Akinola, Dickson A, The Cyber Crime and Internet and Internet Sexual Exploitation of Children, All Student Theses Governors State University, Amerika Serikat, 2017.

Gintings, Valentina, et al, Buku Panduan Terminologi Perlindungan Anak dari Eksploitasi,

Deputi Bidang Perlindungan Anak Kementerian Pemberdayaan Perempuan dan Perlindungan Anak, Jakarta, 2019.

Hagan, Frank E, Pengantar Kriminologi: Teori, Metode, dan Perilaku Kriminal, Pranadamedia, Jakarta, 2013.

Veegar, J, K, Realitas Social, Gramedia Pustaka Utama, Jakarta, 1990.

\section{Artikel Jurnal}

Akub, M, Syukri, 'Pengaturan Tindak Pidana Mayantara (Cyber Crime) dalam Sistem Hukum Indonesia', Jurnal Hukum Universitas Muslim Indonesia, Vol 20, No 2, 2018. L, Murphy, Ly, T, and Fedoroff, J.P. 'Understanding Online Child Sexual Exploitation Offenses', Curr Psychiatry Rep, Vol 18, No 74, 2016. 
Kloess, Juliane, A, Anthony R. Beech and Leigh Harkins, 'Online Child Sexual Exploitation: Prevalence, Process, and Offender Characteristics', Trauma, Violence, $\mathcal{E}$ Abuse, Vol. 15 (2), 2014.

Budi Irawanto, "Mereguk Kenikmatan Di Dunia Maya Virtualitas Dan Penubuhan Dalam Cyber Sex", kawistara, vol 7, no 1, 22 april 2017, hal 30-40

Ummu Hani, dkk. "Kontrol Diri Terhadap Perilaku Cyber Sex Pada Remaja". PSYCHOPOLYTAN jurnal psikologi, Vol 3, No 2, Februari 2020 Hal 126-132

\section{Peraturan Perundang-undangan}

Undang-Undang Nomor 44 Tahun 2008 tentang Pornografi, Lembaran Negara Republik Indonesia (LNRI) Tahun 2008 Nomor 4928.

Undang-Undang Nomor 17 Tahun 2016 tentang Penetapan Peraturan Pemerintah Pengganti Undang-Undang Nomor 1 Tahun 2016 tentang Perubahan Kedua Atas Undang-Undang Nomor 23 tahun 2002 tentang Perlindungan Anak Menjadi Undang-Undang, Lembaran Negara Republik Indonesia (LNRI) Tahun 2016 Nomor 5946.

Undang-Undang Nomor 21 Tahun 2007 tentang Tindak Pidana Perdagangan Orang, Lembaran Negara Republik Indonesia (LNRI) Tahun 2007 Nomor 4720.

Undang-Undang Nomor 19 Tahun 2016 tentang Perubahan Atas Undang-Undang Nomor 11 Tahun 2008 tentang Informasi dan Transaksi Elektronik, Lembaran Negara Republik Indonesia (LNRI) Tahun 2016 Nomor 5952.

\section{Internet}

Prasasti, Giovani, Dio, UNICEF: Waspadai Kejahatan pada Anak di Dunia Maya Selama Pandemi COVID-19, https://m.liputan6.com/health/read/4235421/unicefwaspadai-kejahatan-pada-anak-di-dunia-maya-selama-pandemi-covid-19, diakses tanggal 11 November 2020.

Siaran Pers Nomor: B-108/Set/Rokum/MP 01/06/2020, Hindari Kejahatan Online, Lakukan Edukasi Internet Aman untuk Anak Berulang Kali, https://www.kemenpppa.go.id/index.php/page/read/29/2731/hindari-kejahatanonline-lakukan-edukasi-internet-aman-untuk-anak-berulang-kali, diakses tanggal 20 November 2020.

Sofian, Ahmad, Perlindungan Anak dari Eksploitasi Seksual Online Selama Covid-19, https://business-law.binus.ac.id/2020/05/29/perlindungan-anak-dari-eksploitasiseksual-online-selama-covid-19/, diakses tanggal 10 November 2020.

Webinar FISIP UI 2020, Mencegah dan Membatasi Cyber Crime di Masa Pandemi, https://fisip.ui.ac.id/mencegah-dan-membatasi-cyber-crime-di-masa-pandemi/, diakses tanggal 20 November 2020.

Laporan survei internet asosiasi penyedia jasa internet Indonesia (APJII) 2019-2020 Q2. 